\title{
RESPON BURSA SAHAM TERHADAP STRATEGI DIVERSIFIKASI PENDAPATAN PERBANKAN
}

\author{
Helmi Rafif ${ }^{1}$, Yosman Bustaman ${ }^{2}$
}

${ }^{1}$ Universitas Bina Nusantara, Jakarta, Indonesia

${ }^{2}$ Swiss German University, Tangerang, Indonesia

\section{Article Information}

Received: 24 March 2020

Accepted: 27 May 2020

Published: 6 July 2020

DOI: $10.33555 /$ ijembm.v7i2.127

Corresponding Author:

Helmi Rafif

Jakarta, Indonesia

Email: helmi.rafif95@gmail.com

ISSN $\quad 2338-8854$

eISSN 2620-9918

\begin{abstract}
ABSTRAK
Kami mengevaluasi reaksi pasar saham Indonesia terhadap strategi diversifikasi pendapatan perbankan pada periode 2009-2016. Reaksi pasar diukur dengan rasio kapitalisasi ekuitas pasar terhadap ekuitas nilai buku $(M B)$ dan kelayakan atau solvabilitas pasar diproksi dengan skor $Z$ berbasis pasar bank. Dengan menggunakan regresi data panel, kami menemukan bahwa semakin tinggi tingkat diversifikasi respons pendapatan bank secara positif oleh pasar yang ditunjukkan oleh peningkatan rasio permodalan bank dan solvabilitas pasar. Ini menunjukkan bahwa diversifikasi pendapatan dapat menghasilkan dampak signifikan pada profitabilitas bank dan mengurangi kemungkinan kegagalan bank. Selain itu hasil kami mengungkapkan bahwa semakin besar ukuran bank, semakin berisiko bank, namun bank-bank besar ini dapat mencapai kapitalisasi ekuitas pasar yang lebih tinggi yang melindungi mereka dari masalah kepailitan. Bank yang memiliki respon modal ekuitas buku besar positif oleh pasar, hal ini ditunjukkan oleh hubungan positif antara variabel ini dan skor Z.
\end{abstract}

Kata kunci: Diversifikasi Pendapatan Perbankan, Kegagalan Bank, Profitabilitas Bank, Kapitalisasi, Pasar Saham Indonesia, Z Score

\begin{abstract}
We evaluate how the Indonesian stock market has reacted to the banking diversification revenue strategy in the period of 2009-2016. The market reactions are measured by the ratio of market equity capitalization to its book value equity $(M B)$ and market viability or solvency is proxied by the bank's market-based $Z$ score. Using panel data regression, we find that the higher the level of diversification of bank revenue response positively by the market indicating by improving on banks' capitalization ratio and market solvency. It shows that revenue diversification could produce a significant impact on bank profitability and reduce the probability of bank failure. Additionally, our results reveal that the larger size of the bank, the riskier the bank, however, these larger banks could achieve higher market equity capitalization that protects them from insolvency problems. Banks having large book equity capital response positively by the market, it indicates a positive relationship between this variable and $Z$ score.
\end{abstract}

Keywords: Bank Diversification, Bank Failure, Profitability, Capitalization, Indonesian Stock Market, Z-Score 


\section{Background}

Dalam beberapa dekade terakhir, diversifikasi pendapatan di industri perbankan telah menarik banyak perhatian. Industri perbankan di Cina secara perlahan berganti dari sumber pendapatan tradisional ke sumber pendapatan campuran interest income dan non-interest income. Rata-rata porsi sumber pendapatan non-interest income pada tahun 20002008 lebih besar dari pada tahun 19861999 yaitu $18,9 \%$ menjadi $22,17 \%$ (Li \& Zhang, 2013). Industri perbankan di Amerika, porsi non-interest income dalam struktur pendapatan mengalami kenaikan dari 1993 sebesar 35\%, lalu naik ke 44\% pada tahun 2003 (DeYoung \& Torna, 2013). Sedangkan industri perbankan di Eropa, porsi non-interest income dalam total pendapatan bertumbuh dari 26\% pada tahun 1989 ke 41\% pada tahun 1998 (Lepetit, Nys, Rous, \& Tarazi, 2008a) (Lepetit, Nys, Rous, \& Tarazi, 2008b) (Lepetit et al., 2008), negara ASEAN penelitian diversifikasi produk perbankan dan dampaknya terhadap marjin bank dan risiko di dokumentasikan oleh (Bustaman, Ekaputra, Prijadi, \& Husodo, 2016) (Bustaman, Ekaputra, Husodo, \& Prijadi, 2017) Dalam pergerakan jangka panjang yang telah dijabarkan, Bank tidak lagi tergantung pada interest income.

Peningkatan porsi non-interest income dalam struktur pendapatan di industri perbankan berbagai negara dipicu oleh adanya kompetisi antar intitusi keuangan dan deregulasi keuangan (Hidayat, Kakinaka, \& Miyamoto, 2012). Kompetisi dan deregulasi keuangan terjadi karena adanya inovasi dalam informasi, komunikasi, dan teknologi (DeYoung danTorna, 2013) Kompetisi dan deregulasi tidak hanya berdampak bagi industri perbankan saja, tetapi juga meningkatkan pertumbuhan pasar modal secara substansial (Edirisuriya, Gunasekarage, \& Dempsey, 2015)(Edirisuriya et al., 2016).
Di Indonesia, Bank Indonesia telah mengadopsi kebijakan perbankan untuk mendorong bank-bank komersial untuk mendiversifikasi pendapatan mereka. Salah satu kebijakannya yaitu rasio fee based income telah menjadi indikator profitabilitas bank penting bagi Bank Indonesia (Hidayat et al., 2012). Berdasarkan data statistik perbankan Indonesia dari tahun 2009-2016 yang dikeluarkan OJK, porsi non-interest income terhadap pendapatan operasional mengalami peningkatan. Pada Bank Umum mengalami pertumbuhan dari $18 \%$ pada tahun 2009 menjadi $27 \%$ pada tahun 2016. Pada Bank Persero mengalami pertumbuhan dari $12 \%$ pada tahun 2009 menjadi $28 \%$ pada tahun 2016 .

Oleh karena itu, peningkatan diversifikasi pendapatan yang dilakukan oleh bankbank di Indonesia menjadi salah satu pertimbangan dalam analisis yang dilakukan pelaku pasar modal di Indonesia. Hal itu disebabkan sektor industri keuangan merupakan sektor yang paling berpengaruh di Bursa Efek Indonesia. Selama 5 tahun terakhir selalu menduduki posisi pertama dalam kapitalisasi pasar di JASICA (Jakarta Stock Exchange Industrial Classification). Prinsip ini sejalan dengan penelitian Edirisuriya et al., (2016) bahwa sektor yang paling berkontribusi signifikan bagi kapitalisasi pasar serta likuiditas di pasar modal suatu negara maka menjadi perhatian pelaku pasar modal.

Dengan masih terbatasnya penelitian mengenai pengaruh diversifikasi pendapatan respon pasar modal yang ada selama ini, beberapa artikel terbaru yang berhubungan dengan diversifikasi produk perbankan banyak menghubungkan antara dampak diversifikasi terhadap marjin bank (Carbó Valverde \& Rodríguez Fernández, 2007) risiko ((Bustaman et al., 2017) (Williams, 2016)) kompetisi atau market power 
(Nguyen, Skully \& Perera, 2012b). Sementara itu dampak market power perbankan terhadap ekspansi produk diversifikasi dianalisis oleh (Nguyen, Skully, \& Perera, 2012a) (Nguyen, Perera, \& Skully, 2016). dan sebaliknya investigasi antara berkem-bangnya produk non tradisional perban-kan dan pengaruhnya terhadap market power secara komprehensif dilakukan oleh (Carbó Valverde \& Rodríguez Fernández, 2007) di Eropa dan (Zouaoui \& Zoghlami, 2020) di MENA countries. Penelitian mengenai dampak diversifikasi perbankan terhadap valuasi nilai bank masih sangat sedikit, diantaranya yang sudah melakukan adalah (Laeven et al., 2007) di perbankan 43 negara dan (Guerry \& Wallmeier, 2017) pada perbankan Eropa serta serta (Edirisuriya et al., 2015) di Asia Selatan, dan perbankan Jepang dianalisis oleh (Sawada, 2013), sehingga dengan penelitian ini diharapkan kami memberikan kontribusi terhadap literatur dampak diversifikasi produk perbankan terutama di perbankan Indonesia.

\section{Literature Review}

Penelitian awal dari implikasi dan kajian teori tentang lembaga intermediary menyebutkan bahwa imbal hasil akan meningkat bila bank melakukan diversifikasi (Diamond \& Dybvig, 1983) (Ramakrishnan \& Thakor, 1984). Diversifikasi akan berdampak pada besaran biaya yang dikeluarkan oleh bank, dimana biaya lebih murah dalam meyeleksi dan memonitor debitur sesuai dengan peran bank dalam model delegated investment monitoring (Diamond, 1997) (Diamond, 1991). Bukan hanya diversifikasi produk, diversifikasi yang dilakukan lintas geografis dan lintas sektor akan meningkatkan keuntungan dan akan menciptakan stabilitas keuangan (A. N. Berger \& DeYoung, 2001).
Teori manajemen keuangan (corporate finance) mengatakan bahwa bank haruslah fokus pada satu bidang bisnis atau sektor tertentu sehingga mereka mendapatkan keuntungan dari keahlian yang mereka miliki dan akan mengurangi problem agensi (P. G. Berger \& Ofek, 1995) Dennis et al, 1997). (Denis \& Denis, 1995) memberikan bukti bahwa perusahaan haruslah fokus agar terhindar dari penurunan nilai-diversifikasi akibat agensi problem. Sementara itu Berger dan Ofek (1996) melihat terjadi ketidakefisienan biaya pada perusahaan yang terdiversifikasi jika dibandingkan degan keuntungan yang akan didapat sehingga menurunkan nilai perusahaan. Selanjutnya diversification discount - penurunan nilai perusahaan karena diversifikasi tersebut mungkin saja terjadi karena terlalu banyaknya jenis operasional (konglomerasi) sehingga bank kehilangan fokus (Demsetz \& Strahan, 1997).

Sektor yang paling berpengaruh dalam kapitalisasi pasar dan likuiditas di bursa efek suatu negara menjadi perhatian pelaku pasar modal (Edirisuriya et al.,2016). Di Indonesia, sektor industri keuangan merupakan sektor yang paling berpenga-ruh di Bursa Efek Indonesia. Selama 5 tahun terakhir selalu menduduki posisi pertama dalam kapitalisasi pasar di JASICA (Jakarta Stock Exchange Industrial Classification). Oleh karena itu, lingkungan eksternal maupun internal yang dihadapi sektor keuangan di Indonesia menjadi perhatian pelaku pasar atau investor. Lingkungan eksternal yang dihadapi sektor keuangan di Indonesia adalah ketatnya persaingan perekonomian di dunia, perubahan teknologi, dan adanya deregulasi keuangan di Indonesia. Salah satu lingkungan internal yang dihadapi sektor keuangan di Indonesia adalah bank-bank komersial didorong untuk mendiversikasi berbagai layanan keuangan yang akan ditawarkan ke nasabah. 
Hasil penelitian terdahulu yang mencari hubungan diversifikasi pendapatan terhadap faktor respon pasar modal masih terbatas. Hal ini dikarenakan tidak semua kapitalisasi pasar dan likuiditas suatu pasar modal di suatu negara didominasi oleh sektor perbankan. Contohnya bursa efek di Dhaka, Bombay, Karachi, dan Colombo memiliki kontribusi yang signifikan bagi kapitalisasi pasar dan likuiditas pasar modal disana (Edirisuriya et al. 2016). Bahkan bursa efek di Amerika, sektor teknologi informasi memiliki kapitalisasi yang paling berkontribusi besar.

Penelitian terdahulu dilakukan oleh Edirisuriya et al. (2016) pada 86 bank yang mewakili empat negara di Asia Tengah. Periode penelitian mereka tahun 1999 hingga 2012. Mereka melakukan pengujian diversifikasi pendapatan terhadap respon pasar modal dengan tolak ukur market valuation (MEBE), stock return volatility (SDRET), dan market solvency (Z-score). Hasil temuan mereka adalah ketika bank mendiversifikasi interest income maka market-tobook value menjadi lebih tinggi dan meningkatkan solvabilitas.

Hasil penelitian lebih awal dari yang diteliti oleh Edirisuriya et al. (2016) dikerjakan oleh Sawada (2013) untuk pasar Jepang. Berbeda dengan yang dilakukan Edirisuriya et al. (2016), Sawada (2013) menitik beratkan pada dampak diversifikasi perbankan terhadap nilai perbankan dan juga risiko yang muncul. Respon pasar modal diukur dengan Tobin Q dan MEBE. Hasilnya adalah diversifikasi pendapatan memiliki hubungan positif dengan market value karena bank di Jepang memiliki customer base yang kuat dan menjalin hubungan yang erat dengan klien mereka sehingga pelaku pasar modal dapat memprediksi diversifikasi pendapatan dapat menguntungkan bagi bank-bank Jepang. Namun diversifikasi tidak secara signifikan berdampak pada risiko perbankan. Lebih jauh Sawada (2013) juga mencatat bahwa respon diversifikasi terhadap nilai dan risiko perbankan tergantung karakteristik perbankan seperti bentuk organisasi bank dan kinerja dari bisnis inti perbankan tersebut. Sejalan dengan penelitian Sawada (2013), (Baele, De Jonghe, \& Vander Vennet, 2007) . Baele et al. (2007) melakukan penelitian pada bankbank di 17 negara Eropa. Mereka peneliti pengaruh diversifikasi pendapatan dan aset bank terhadap respon pasar modal dengan tolak ukur Tobin Q. Hasil yang ditemukan adalah diversifikasi pendapatan berpengaruh secara positif terhadap Tobin Q. Hasil Baele et al. (2007) ini sebenarnya di kuatkan oleh temuan Sawada (2013) bahwa diversifikasi berpengaruh positif terhadap respon pasar, namun Baele et al (2007) mendokumentasikan bahwa risiko sistemik pada perbankan Eropa meningkat dengan diversifikasi produk ini terutama yang dilakukan pada produk keuangan yang memiliki unsur spekulasi.

\section{Data and Method}

\subsection{Data}

Penelitian ini menggunakan data pada bank yang terdaftar di Bursa Efek Indonesia. Total terdapat 44 bank yang terdaftar di BEI hingga tahun 2016. Peneliti mengambil data yang meliputi statement of financial position dan income statement dari bank-bank tersebut dari periode 2009-2016.

Pengambilan sampel dalam penelitian ini berdasarkan keperluan penelitian (purposive sampling). Pertama, Bank yang terdaftar di Bursa Efek Indonesia. Kedua, Bank yang menyertakan laporan keuangan yang lengkap untuk periode tahun 2009-2016 sebagai perhitungan penelitian. Ketiga, Bank yang selalu mencetak laba selama periode tahun 2009-2016. Selain itu, juga dianalisa dan dijadikan pertimbangan kondisi ekonomi 
makro pada periode yang ditentukan yaitu kondisi ekonomi makro berdasarkan GDP (Gross Domestic Product) dan inflasi. Pergerakan pertumbuhan ekonomi akan sangat berdampak kepada masyarakat untuk melakukan investasi di pasar modal maupun pasar real, yang akan berdampak pada fluktuasi dan ekpektasi harga pasar. Perubahan angka inflasi dan suku bunga akan memberikan acuan terhadap ekpektasi tingkat pengembalian dari investasi.

Data laporan tahunan atau laporan keuangan bank melalui situs resmi Bursa Efek Indonesia (www.idx.co.id). Sedangkan, data harga saham melalui situs resmi Yahoo Finance (www.finance.yahoo.com). GDP (Gross Domestic Product) dan inflasi melalui situs resmi World Bank (http://data.worldbank.org/). Store Loyalty

\subsection{Methodology}

Tujuan penelitian ini menganalisis pengaruh diversifikasi pendapatan bank terhadap respon pasar modal. Oleh karena itu, dependen variabel respon pasar modal diukur dengan 3 tolak ukur berdasarkan penelitian Edirisuriya et al. (2016).

Pertama, market valuation merupakan merupakan rasio yang dihitung dengan market-equity capitalization dibagi book value equity. Kedua stock return volatility yang dihitung dengan Standar Deviation of Bank Monthly Stock Return (SDRET). Ketiga, market viability yang dihitung dengan z-score, rumusnya sebagai berikut:

$$
Z-\text { score }=\frac{\left(k_{i, t}+\mu_{i, t}\right)}{\sigma_{i, t}}
$$

$k_{i, t}$ adalah rasio perusahaan $i$ dari market value of equity terhadap market value of asset untuk keuangan $t$ tahun (rata-rata 7 tahun sebelumnya), $\mu_{\mathrm{i}, \mathrm{t}}$ adalah return on asset (ROA) perusahaan $i$ berbasis pasar untuk periode tahun $t$ (rata-rata 7 tahun sebelumnya), dan $\sigma_{\mathrm{i}, \mathrm{t}}$ adalah standard of deviation return of assets perusahaan $i$ untuk keuangan $t$ tahun (rata-rata 7 tahun sebelumnya). Sedangkan $\mu_{i, t}$ didapat dengan rumus:

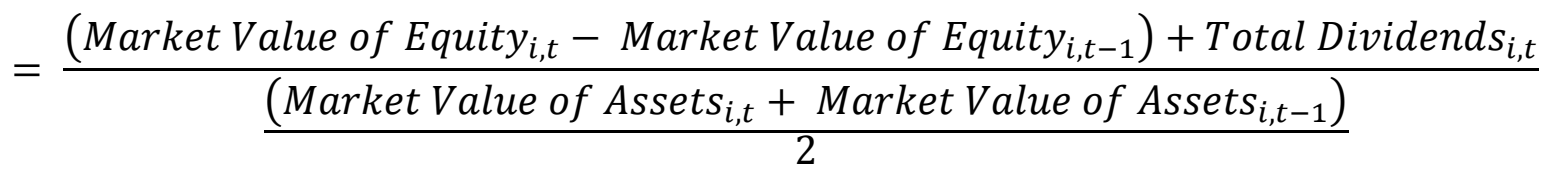

Lalu, perhitungan market value of assets didapat dari:

$$
\begin{gathered}
=\text { Market Value of Equity }+ \text { Book Value Preference Share } \\
+ \text { Book Value of Longterm Debt }
\end{gathered}
$$

Variabel independen penelitian ini yaitu diversifikasi pendapatan bank. Berdasarkan penelitian Lepetit et al. (2008), diversifikasi pendapatan bank dibagi menjadi 3 tolak ukur yaitu net noninterest income (NNII), commission income (COM), dan trading income
(TRAD). NNII didapat dari hasil perhitungan netnon-interest income dibagi net operating income. Net non-interest income didapat dari non-interest income dikurang non-interest expenses. Net operating income didapat dapat dari penjumlahan antara net non-interest 
income dengan net interest income. $\mathrm{COM}$ didapat dari net commission income dibagi dengan net operating income. TRAD dihitung dengan net trading income dibagi dengan net operating income.

\subsection{Regression Model}

Setelah mendapatkan model yang terbaik untuk melakukan pengujian regresi panel data, berikutnya adalah penjelasan dari metode yang akan digunakan untuk menganalisis pengaruh diversifikasi pendapatan bank respon pasar modal dengan GDP, inflasi, size, capitalization, dan liquidity sebagai variabel kontrol. Penelitian ini terdapat satu model persamaan regresi yaitu:

$$
\begin{aligned}
& Y_{i t}=\beta_{1}+\beta_{2} N_{I I}+\beta_{3} C O M_{i t}+\beta_{4} T R A D_{i t}+\beta_{5} G D P_{i}+\beta_{6} I N F L A S I_{i}+ \\
& \beta_{7} \operatorname{LOG}(T A)_{i t}+\beta_{8} E_{\text {EUITY }}+\beta_{9} L D R_{i t}+\varepsilon_{i t}
\end{aligned}
$$

$Y_{i t}$ merupakan variabel dependen respon pasar modal pada bank $i$ periode $t$. Variabel dependen respon pasar modal diukur masing-masing dengan SDRET, zscore, dan MEBE. NII it merupakan net non-interest income pada bank $i$ periode $t$. COM $_{i t}$ merupakan commission income pada bank i periode $t$. TRAD $i t$ merupakan trading income pada bank $i$ periode $t$. $G D P_{i}$ merupakan pertumbuhan gross

domestic product di Indonesia pada periode $t$. INFLASI $i$ merupakan tingkat inflasi di Indonesia pada periode $t$. $L O G(T A)_{\text {it }}$ merupakan ukuran bank pada bank $i$ periode $t$. EQUITY $i t$ merupakan besarnya kapitalisasi pada bank $i$ periode t. $L D R_{\text {it }}$ merupakan tingkat likuidutas pada bank $i$ periode $t$.

\section{Result}

\subsection{Descriptive statistics}

Tabel di bawah merupakan hasil analisis statistik deskriptif yang terdiri dari variabel dependen yaitu respon pasar modal.

Tabel 1. Hasil Statistik Deskriptif Sumber: Eviews 9.0, diedit oleh penulis

\begin{tabular}{lrrr} 
& SDRET & \multicolumn{1}{c}{ ZSCORE } & \multicolumn{1}{c}{ MEBE } \\
\hline Mean & 0.141 & 3.303 & 1.466 \\
\hline Median & 0.104 & 2.909 & 1.177 \\
\hline Maximum & 0.581 & 32.083 & 5.826 \\
\hline Minimum & 0.000 & -0.978 & -9.375
\end{tabular}

Tabel 2. Hasil Statistik Deskriptif Sumber: Eviews 9.0, diedit oleh penulis

\begin{tabular}{lcccccccc} 
& NNII & COM & TRAD & GDP & INFLASI & LOGTA & EQUITY & LDR \\
\hline Mean & -0.452 & 0.133 & 0.066 & 0.054 & 0.053 & 13.628 & 0.118 & 0.769 \\
\hline Median & -0.463 & 0.111 & 0.040 & 0.053 & 0.053 & 13.676 & 0.116 & 0.808 \\
\hline Maximum & 0.661 & 0.722 & 0.462 & 0.062 & 0.064 & 15.016 & 0.238 & 1.438 \\
\hline Minimum & -2.041 & 0.008 & 0.001 & 0.046 & 0.035 & 11.977 & 0.060 & 0.353
\end{tabular}


Variabel dependen respon pasar modal memiliki 3 tolak ukur yaitu SDRET, zscore, dan MEBE. Variabel independennya terdiri dari 6 termasuk diantaranya variabel independen dan variabel kontrol yaitu diversifikasi pendapatan, gross domestic product (GDP), inflasi, size yang diukur dengan (LOG TA), capitalization yang diukur dengan (EQUITY), dan likuiditas yang diukur dengan (LDR). Variabel diversifikasi pendapatan terdiri dari 3 tolak ukur yaitu net non-interest income (NNII), commission income (COM), dan trading income (TRAD).

Berdasarkan data deskriptif diatas, ratarata SDRET adalah 0.141. Nilai maksimumnya diperoleh oleh BBNP pada tahun 2009 dengan nilai 0.581. BBNP pada tahun 2010 hingga 2012 memperoleh nilai minimum 0.000 yang artinya selama tahun tersebut, saham dengan kode BBNP tidak menghasilkan return sama sekali atau harga sahamnya tidak bergerak.

Berdasarkan data deskriptif diatas, ratarata $\mathrm{z}$-score yang diukur dengan nilai pasar adalah 3.303. Nilai z-score maksimum diperoleh BBNP pada tahun 2016. Lalu, BACA pada tahun 2015 memperoleh z-score dengan nilai minimum sebesar -0.978 .

Berdasarkan data deskriptif diatas, ratarata MEBE adalah 1.466. Nilai maksimumnya adalah 5.826 yang diperoleh BNII pada tahun 2010. Data ini menjelaskan bahwa kemungkinan investor memiliki perspektif bahwa BNII memliki prospek yang bagus kedepannya. Hal itu ditunjukkan dari nilai MEBE yang positif. Nilai terendah diperoleh BACA pada tahun 2009 dengan nilai -9.375 .

Berdasarkan data deskriptif diatas, ratarata NNII adalah -0.452 yang diartikan bahwa komposisi NNII didalam struktur pendapatan pada sampel penelitian yaitu 26 Bank yang terdaftar di BEI masih kecil. Hal ini ditunjukkan nilai net non-interest income yang negatif. Penulis mengukur NNII dengan membagi net non-interest income dengan net operating income. Net non-interest income didapat dengan noninterest income dikurang non-interest expense. Oleh karena itu, nilai negatif dari NNII disebabkan oleh non-interest income belum bisa menutupi besarnya noninterest expense. Nilai maksimum dari NNII adalah 0.661 yang diperoleh BBCA pada tahun 2012. Nilai minimum dari adalah NNII adalah -2.041 yang diperoleh BACA pada tahun 2010.

Berdasarkan data deskriptif diatas, ratarata COM adalah 0.133. Nilai maksimum COM adalah 0.722 yang diperoleh BVIC pada tahun 2010. Hal ini menunjukkan bahwa commission income BVIC pada tahun 2010 lebih besar daripada trading income dalam komposisi non-interest income. Nilai minimum COM adalah 0.008 yang diperoleh BJTM patah tahun 2010.

Berdasarkan data deskriptif diatas, rata-rata TRAD adalah 0.066. Nilai maksimum dari TRAD adalah 0.462 yang diperoleh BBCA pada tahun 2015. Nilai minimum dari TRAD adalah 0.001 yang diperoleh BTPN tahun 2015. Hal ini menunjukkan bahwa trading income BTPN pada tahun 2015 lebih kecil daripada commission income dalam komposisi non-interest income.

\subsection{Output Regression}

Model regresi yang terbaik sudah ditentukan berdasarkan uji Chow dan uji Hausman. Hasil yang didapat yaitu menggunakan random effect model. Setelah ditentukan modelnya, hasil regresi siap untuk diinterprestasikan serta digunakan untuk uji hipotesis dari penulis. Berikut ini adalah hasil output dari ketiga jenis uji yang menggunakan Eviews 9.0: 
Tabel 3. Hasil Output Regresi Diversifikasi Pendapatan terhadap Respon Pasar Modal

Sumber: hasil output Eviews 9, diedit oleh penulis

\begin{tabular}{|c|c|c|c|c|c|c|}
\hline & \multicolumn{2}{|l|}{ SDRET } & \multicolumn{2}{|l|}{ Zscore } & \multicolumn{2}{|l|}{ MEBE } \\
\hline NNII & 0.0144 & & 0.1916 & & 0.7746 & $* * *$ \\
\hline (t-stat) & 0.6222 & & 0.8078 & & 0.0230 & \\
\hline $\mathrm{COM}$ & -0.0699 & & 1.2405 & & 0.7020 & \\
\hline (t-stat) & 0.4354 & & 0.6289 & & 0.5212 & \\
\hline TRAD & -0.0957 & & 1.6442 & & 0.3996 & \\
\hline (t-stat) & 0.4018 & & 0.6041 & & 0.7684 & \\
\hline GDP & -5.1519 & $* * *$ & 35.8882 & & 39.8313 & $* * *$ \\
\hline (t-stat) & 0.0000 & & 0.2317 & & 0.0024 & \\
\hline INFLASI & -5.1151 & $* * *$ & -45.3516 & $* * *$ & -4.3176 & \\
\hline (t-stat) & 0.0000 & & 0.0087 & & 0.5610 & \\
\hline LOG TA & 0.0032 & & -0.1173 & & 0.3239 & \\
\hline (t-stat) & 0.8194 & & 0.8201 & & 0.1248 & \\
\hline EQUITY & 0.3301 & & 22.3702 & $* * *$ & -6.5523 & $* *$ \\
\hline (t-stat) & 0.1851 & & 0.0014 & & 0.0277 & \\
\hline LDR & 0.0191 & & -0.1316 & & 0.1351 & \\
\hline (t-stat) & 0.6633 & & 0.9129 & & 0.7934 & \\
\hline Cons. & 0.6154 & $* * *$ & 2.6179 & & -3.9778 & \\
\hline (t-stat) & 0.0045 & & 0.7229 & & 0.1912 & \\
\hline R-squared & 0.28902 & & 0.088162 & & 0.14485 & \\
\hline $\begin{array}{l}\text { Adjusted R- } \\
\text { squared }\end{array}$ & 0.26413 & & 0.060943 & & 0.11047 & \\
\hline F-statistic & 11.61426 & & 3.238968 & & 4.21341 & \\
\hline Prob (F-statistic) & 0.00000 & & 0.004638 & & 0.00011 & \\
\hline Jumlah Observasi & 208 & & 208 & & 208 & \\
\hline
\end{tabular}

\subsection{Pengaruh Diversifikasi Pendapatan Bank terhadapa Respon Pasar Modal}

Hipotesis pada penelitian ini menyatakan bahwa diversifikasi pendapatan bank berpengaruh terhadap respon pasar modal. Berdasarkan hasil regresi panel data yang terdapat pada tabel 3 ditemukan bahwa variabel diversifikasi pendapatan dengan tolak ukur NNII, COM, dan TRAD memiliki hasil yang berbeda tergatung dari tolak ukur respon pasar modal yang terdiri dari SDRET, z-score, dan MEBE. Hasil uji variabel dependen risiko dengan tolak ukur SDRET dan z-score tidak dipengaruhi secara signifikan oleh diversifikasi pendapatan bank. Saat MEBE diuji sebagai varibel dependen didapatkan hasil yang berpengaruh secara signifikan.. Semua hasil uji pada NNII, COM, dan TRAD bersifat positif sehingga setiap kenaikan porsi net non-interest income, commission income, dan trading income dapat menaikkan market valuation. Jadi dapat disimpulkan bahwa hipotesis diterima.

Hasil ini sejalan dengan penelitian yang dilakukan oleh Edirisuriya et al. (2016), Sawada (2013), dan Baele et al. (2007) bahwa diversifikasi pendapatan bank berpengaruh signifikan terhadap market valuation. Hubungan yang ditemukan adalah semakin besarnya diversifikasi pendapatan dalam struktur pendapatan bank maka akan meningkatkan market valuation.

Hal ini disebabkan selama 5 tahun terakhir sektor finansial menempati posisi pertama dalam kapitalisasi pasar di Bursa 
Efek Indonesia. Oleh karena itu, kebijakan bank yang salah satunya melakukan diversifikasi pendapatan menjadi menarik perhatian pelaku pasar modal (Edirisuriya et al., 2016). Ketertarikan perhatian pelaku pasar modal terhadap diversifikasi pendapatan bank tercemin pada naiknya market valuation yang diukur MEBE.

\subsection{Pembahasan Variabel Kontrol}

Hubungan variabel kontrol makro ekonomi yaitu gross domestic product (GDP) dan inflasi dengan variabel dependen respon pasar modal memiliki hasil yang sama. Gross domestic product (GDP) dan inflasi berpengaruh secara signifikan terdapat respon pasar modal. Gross domestic product (GDP) berpengaruh signifikan yang bersifat negatif terhadap SDRET dan bersifat positif terhadap MEBE. Dapat disimpulkan bahwa semakin bertumbuhnya GDP di Indonesia maka menurunkan volatilitas return saham dan meningkatkan market valuation. Hal ini karena bertumbuhnya GDP mencerminkan bertambahnya investasi di Indonesia secara langsung maupun tidak langsung. Bertambahnya investasi secara tidak langsung dilakukan melalui pasar modal mencerminkan kepercayaan investor bahwa berinvestasi di Indonesia dapat memberikan keuntungan kedepannya. Inflasi berpengaruh signifikan negatif terhadap SDRET dan z-score. Dapat disimpulkan bahwa semakin meningkatnya inflasi maka menurunkan volatilitas return saham dan menurunkan viabilitas pasar.

Hubungan variabel kontrol karakteristik bank yaitu size, capitalization, dan liquidity terhadap respon pasar modal memiliki hasil yang beragam. Karakteristik bank yaitu size dan liquidity tidak berpengaruh secara signifikan terhadap respon pasar modal. Hasil yang berbeda didapat pada karakteristik bank capitalization yaitu ukuran bank berpengaruh secara signifikan terhadap respon pasar modal yang diukur dengan z-score dan MEBE. Hubungan diantara capitalization terhadap z-score bersifat postif sedangkan terhadap MEBE bersifat negatif. Dapat disimpulkan bahwa semakin tinggi capitalization maka menaikkan viabilitas pasar dan menurunkan market valuation. Hal ini karena capitalization mencerminkan kekuatan keuangan dari bank tersebut.

\section{Conclusion}

Penelitian mengenai diversifikasi pendapatan di industri perbankan banyak dilakukan di berbagai negara benua Asia, Eropa, dan Amerika. Banyak penelitian yang membahas mengenai pengaruh diversifikasi pendapatan terhadap risiko bank, tetapi penelitian yang membahas faktor respon pasar modal masih terbatas. Hal ini dikarenakan tidak semua kapitalisasi pasar dan likuiditas suatu pasar modal di suatu negara didominasi oleh sektor perbankan. Di Indonesia sendiri, belum ada penelitian yang membahas diversifikasi pendapatan di sektor perbankan terhadap respon pasar modal. Padahal Bank Indonesia telah mengadopsi kebijakan perbankan untuk mendorong bank-bank komersial untuk mendiversifikasi pendapatannya dan selama 5 tahun terakhir sektor finansial menempati posisi pertama dalam kapitalisasi pasar di Bursa Efek Indonesia. Oleh karena itu, penelitian ini memiliki tujuan untuk menganalisis pengaruh diversifikasi pendapatan bank terhadap respon pasar modal dengan GDP, inflasi, size, capitalization, dan liquidity sebagai variabel kontrol. Sampel penelitian ini terdapat 26 bank yang terdaftar di Bursa Efek Indonesia periode 2009-2016. Metode purposive sampling digunakan untuk memilih sampel. Analisa model regresi menggunakan software Eviews 9.

Berdasarkan hasil penelitian didapatkan bahwa diversifikasi pendapatan bank berpengaruh signifikan terhadap respon 
pasar modal. Hasil ini sejalan dengan penelitian yang dilakukan oleh Edirisuriya et al. (2016) bahwa diversifikasi pendapatan bank berpengaruh signifikan terhadap market valuation. Hubungan yang ditemukan adalah semakin besarnya diversifikasi pendapatan dalam struktur pendapatan bank maka akan meningkatkan market valuation. Hal ini disebabkan selama 5 tahun terakhir sektor finansial menempati posisi pertama dalam kapitalisasi pasar di Bursa Efek Indonesia. Oleh karena itu, kebijakan bank yang salah satunya melakukan diversifikasi pendapatan menjadi menarik perhatian pelaku pasar modal (Edirisuriya et al., 2016). Ketertarikan perhatian pelaku pasar modal terhadap diversifikasi pendapatan bank tercemin pada naiknya market valuation yang diukur MEBE.

Setelah melakukan analisis terhadap hasil penelitian, peneliti menyadari terdapat keterbatasan dalam penelitian ini, di antaranya Jumlah sampel dalam penelitian hanya 26 bank yang terdaftar di BEI. Jumlah ini tergolong sangat sedikit. Oleh karena itu, data yang digunakan kurang menggambarkan kondisi industri perbankan secara keseluruhan di Indonesia. Penelitian ini merupakan penelitian pertama yang menggabungkan pengaruh diversifikasi pendapatan bank terhadap respon pasar modal di Indonesia.

\section{References}

Baele, L., De Jonghe, O. G., \& Vennet, R. V. (2007). Does the stock market value bank diversification? Journal of Banking and Finance, 31, 19992023.

Berger, A. N., \& DeYoung, R. (2001). The Effects of Geographic Expansion on Bank Efficiency. Journal of Financial Services Research, 19(2-3), 163-184. https://doi.org/10.1023/A:1011159 405433
Berger, P. G., \& Ofek, E. (1995). DiveBerger, P. G., \& Ofek, E. (1995). Diversification's effect on firm value. Journal of Financial Economics, 37(1), 39-65. http://doi.org/10.1016/0304-405X (94)00798-6

Bustaman, Y., Ekaputra, I. A., Husodo, Z. A., \& Prijadi, R. (2017). Impact of interest margin, market power and diversification strategy on banking stability: Evidence from ASEAN-4. Asian Journal of Business and Accounting, 10(1).

Bustaman, Y., Ekaputra, I. A., Prijadi, R., \& Husodo, Z. A. (2016). Impact of loan portfolio diversification and income diversification on interest margin in ASEAN banking market. Pertanika Journal of Social Sciences and Humanities, 24(May).

Carbó Valverde, S., \& Rodríguez Fernández, F. (2007). The determinants of bank margins in European banking. Journal of Banking and Finance, 31(7), 20432063. https://doi.org/10.1016/j .jbankfin.2006.06.017

Demsetz, R. S., \& Strahan, P. E. (1997). Diversification, Size, and Risk at Bank Holding Companies. Journal of Money, Credit and Banking, 29(3), 300. doi: 10.2307/2953695

Denis, D. J., Denis, D. K., \& Sarin, A. (1997). Agency Problems, Equity Ownership, and Corporate Diversification. The Journal of Finance, 52(1), 135-160. doi: $10.2307 / 2329559$

De Young, R., \& Torna, G. (2013). Nontraditional banking activities and bank failures during the financial crisis. Journal Finance Intermediation, 22, 397-421.

Edirisuriya, P., Gunasekarage, A., \& Dempsey, M. (2016). Bank 
diversification, performance and stock market response: Evidence from listed public banks in South Asian countries. Journal of Asian Economics, 41, 69-85.

Hidayat, W. H., Kakinaka, M., \& Miyamoto, H. (2012). Bank risk and non-interest income activities in the Indonesian banking industry. Journal of Asian Economics, 23, 335-343.

Lepetit, L., Nys, E., Rous, P., \& Tarazi, A. (2008). The expansion of services in European banking: Implications for loan pricing and interest margins. Journal of Banking \& Finance, 32, 23252335.

Li, L., \& Zhang, Y. (2013). Are there diversification benefits of increaseing non-interest income in the Chinese banking industry? Journal of Empirical Finance, 24, 151-165.

Otoritas Jasa Keuangan (2013). Statistik Perbankan Indonesia Desember 2012. Departemen Perizinan dan Informasi Perbankan: Otoritas Jasa Keuangan.

Otoritas Jasa Keuangan (2016). Statistik Perbankan Indonesia Desember 2016. Departemen Perizinan dan Informasi Perbankan: Otoritas Jasa Keuangan.

Sawada, M. (2013). How does the stock market value bank diversification? Empirical evidence from Japanese banks. Pacific-Basin Finance Journal, 25, 40-61.
Williams, B. (2016). The impact of noninterest income on bank risk in Australia. Journal of Banking and Finance, 73, 16-37. https://doi.org /10.1016/j.jbankfin.2016.07.019

Zouaoui, H., \& Zoghlami, F. (2020). On the income diversification and bank market power nexus in the MENA countries: Evidence from a GMM panel-VAR approach. Research in International Business and Finance, 52(December 2018). https://doi.org /10.1016/j.ribaf.2020.101186

www.finance.yahoo.com

www.idx.co.id 